\title{
Interview with Irene Hollister
}

LIGHT: We'll just work through background information to start with. So could you talk about your education, where and when you got your degree?

HOLLISTER: I have a Bachelor of Business Administration from the University of Toledo. I grew up in Toledo, Ohio.

LIGHT: Okay. Could you mention your administrative roles at ACM, and specify what years you held those positions.

HOLLISTER: Okay. I was hired as their first staff member in April of 1960.

LIGHT: And who was it who hired you?

HOLLISTER: They apparently set up a committee — typical [laughter] — to recruit a staff member. A man I was working with in my job-a management consulting firm — was a friend of Howard Levin, who I think was the head of the recruiting committee. And he recommended me. I was interviewed by... as I look back at it, this was in Manhattan, and I lived on East $60^{\text {th }}$ and the office was in lower Manhattan where they held the interview. If I remember correctly, it was at night, too, and when I walked into the room where they were going to interview me, it seemed to me that there were 20 people in there! I don't know if there were that many, but there were a lot. So that was my interview, and I passed the interview.

LIGHT: Did you play any other specific administrative roles at ACM, or you held the same position?

HOLLISTER: Well, do you want me to talk about the first office before we go to the next question?

LIGHT: Sure.

HOLLISTER: All right, maybe that would be, you know, sort of logical.

The administrative work for ACM was contracted out to the New York Academy of Sciences building. That building was the former Woolworth mansion, and was on I think $64^{\text {th }}$ Street. Well, it's still there, but I don't know if it's the Academy. And it was run by a woman who was a real martinet [chuckles], and there were other societies I think that they also contracted with. She lived on the upper floors, had her apartment on the upper floors, and ran the New York Academy. They had a staff of two who worked on ACM fulfillment. The man who ran the ACM, his office was in what I'm sure was formally a bathroom. [Laughter] And as I remember it was long and narrow with all white tile. And he had one clerk to help him. So when I was to take over, which was April $1^{\text {st }}$, 1960, the powers that be at ACM must have said, "Well, you can't just let her walk in by herself. Somebody has to introduce her to the man who is doing the work, so that there won't be any hard feelings to begin with.” So I met Dick Hamming at the academy. You're probably familiar with him, eh?

LIGHT: I am, yes. 
HOLLISTER: From Bell Labs. He came in from New Jersey and met me in the lobby of the Academy and took me up on the elevator. I don't remember the other man's name who was with me at the office, but Hamming said, "Mr. So-and-so, this is Irene Hollister. Goodbye.” [Laughs.]

\section{LIGHT: [Laughs.]}

HOLLISTER: I'm not kidding! That was almost exactly the way-- He didn't say, "She's going to do this or that..." "Goodbye," and off he went. If you know, Hamming, then...

My first assignment was to find a place as an office. I can't think of his first name, Moscowitz [?] was secretary at that time, and he was located in Washington. I would go around and look at spaces and when I got one or two that I thought were possibilities, he would come up and bless it. The first office was in a brownstone on $69^{\text {th }}$ Street on the third floor. We were not quite sure whether it was legal.

LIGHT: You mean because it was a residential place?

HOLLISTER: Yes, because you're not allowed to run a business a certain number of feet past the avenue. But anyway, we set up the office and hired one staff member. They then hired Myrtle Kellington as the other staff member, but she was located in Washington because she was... At that time, still employed by the Bureau of Standards. She worked with Franz Alt, notable as a mathematician, and I think she did it part time with her job. But then they hired her full time and for a while she still remained in Washington.

LIGHT: Now, were you a member of any SIGs, or that was not part of your participation?

HOLLISTER: There were no SIGs at that time.

LIGHT: Okay. Were you or are you a member of any other professional organizations?

HOLLISTER: Well, I was a member of the Association of Association Executives.

LIGHT: Okay. Primary area of research—I imagine not relevant.

HOLLISTER: No.

LIGHT: Okay. Did you hold any major positions outside of ACM?

HOLLISTER: No.

LIGHT: Okay. How would you describe your primary contributions to the field, or we might say to the organization? That's a big question.

HOLLISTER: Well, I think one of the first things I decided-well, it was just part of me because of my schooling and my business background, I had been employment manager for Bonwit Teller and Gimble Brothers before going to ACM, and had worked for a management 
consulting firm - that the ACM office would be run as a business, with financial controls, proper hiring, and employment practices, etc. I guess that went along with the feelings of the people who hired me because they gave me a free hand in this area.

LIGHT: As opposed to running it like an academic research organization.

HOLLISTER: Yes. See, I have no computer background, so that was what they were buying, if you will, administrative expertise. Which brings up a point. I tried to think this morning of the tax exempt term.

LIGHT: 501(c)3?

HOLLISTER: Oh god, I thought I'd never forget it! But I couldn't think of it. Well, one of the things I had to work on over the years, and I think it's sort of non-ending. ACM is a not-forprofit organization. It is not a non-profit organization because a non-profit organization is a losing cause. Not-for-profit means that ACM cannot do things for a profit. All right, now where are we?

LIGHT: The big, overarching nature of your contribution.

HOLLISTER: The other major contribution I think, was that from the beginning, I got engaged with Paul Weiss Rifkind Wharton and Tarrison as ACM legal advisors. The lawyers in New York. And so we got good legal advice. In February I had dinner with Pat Ryan, and she actually made me think of it because she said to me at one point that they had recently given ACM very good legal advice.

LIGHT: Do you remember, did ACM have an official position on patenting versus copyrighting?

HOLLISTER: No. Not as far as I know.

LIGHT: Okay.

HOLLISTER: The Turing Award was the first ACM award. In addition to the award they would give gifts to the awardee. There are organizations that class rings, plaques, awards, and so forth. But I decided that I didn't like their style, and I thought that the awards should really have some intrinsic value. So from the first award on (I think they still do it; I'm not sure), we went to Tiffany's for our awards. When the awardee got a piece of silver, it was worth something.

LIGHT: Well, that makes following on with the next question, which is about gender! [Laughs] Now would a man go to Tiffany's to buy the-- I'm sorry. I don't mean to interrupt. If you want to go on with your other contributions, be my guest.

HOLLISTER: No, no, that's all right.

LIGHT: One of my special interests is how does it make a difference, if at all, that you were a woman in your position as opposed to a man? I don't know if in this particular story you think it 
makes a difference, or you were reflecting on other moments. But I know there are increasing numbers of historians who are very concerned about the gendering of computer science from its early days. How did that manifest itself in your career?

HOLLISTER: I don't know. It's hard to tell. I know that Don Madden, who was the first executive director-I was their executive secretary. I hated the term. Of course, I always had to tell people in answer to, "What do you do?" and I would have to say "I am the executive secretary." I think maybe those days are gone. They don't use terms like that anymore. But going back to Tiffany’s Don Madden at one point said, "I want to get my secretary something for Christmas. Would you go to Tiffany's? She has this silver charm bracelet and would you go to Tiffany's and get her a charm?” Well, I went to Tiffany's and-this was a long time ago, Tiffany's informed me they did not carry anything but gold. Times have changed; they now carry silver.

LIGHT: Oh [inaudible].

HOLLISTER: Also, with a volunteer organization that has a paid staff, one has to define what responsibility belongs to the staff and what belongs to the volunteers. It is necessary that the responsibility be defined. For instance, the staff working in the SIG area works so closely with a SIG chairman that there is a tendency on the part of the staff to think they work exclusively for the volunteer. The staff gets a good deal of guidance from the volunteer, but their ultimate responsibility is to the ACM administration. Defining this split invariably presented a challenge.

LIGHT: Are there specific episodes that were particularly tense that you remember during your time?

HOLLISTER: Yeah.

LIGHT: Do you want to comment on it?

HOLLISTER: No, because I don't want to get into personalities. During the early days, there were chapters. We didn't have any SIGs. The chapter volunteers wanted to collect association dues. Their point was that this was a chance for them to contact their membership on a one-toone basis. But what happened is they collected the dues and then put it all together and sent it three or four or five weeks after they'd collected it. In the meantime, people are calling or writing, "Where's my publication?” So that caused considerable membership dissatisfaction. us The fewer steps between the administration of the organization and the membership, the better off you are. And we went through the same situation with the British Computer Society, and that was a real problem.

LIGHT: Really. Could you say a little more about that?

HOLLISTER: Yes. The British Computer Society wanted-- there was a membership agreement between us that for a certain amount of money, BCS could get our publications at membership rates without actually becoming members of ACM, and they wanted to collect the dues. Well, they were not very efficient, although they did have the staff. They just didn't move as fast as 
ACM. We did have that problem until we worked it out through the banking system. But that was a serious problem for a long time.

LIGHT: Okay, so let me just ask again the question of gender, just to see if there's anything else you might want to reflect on about how it might have made a difference or not. Because frankly, I've talked to plenty of people who say, "People make too much of a big deal of it. It wasn't a big deal.” From your perspective, did it make a difference? Not so much?

HOLLISTER: I never felt that there was any problem. I always got the feeling of support and fair treatment.

LIGHT: The next section of the list of questions has to do with your tenure as an ACM officer. I think some of these questions will repeat a little bit of our discussion, so we can move through them as slowly or quickly as you like. So you talked already about how you got your job at ACM. Is there anything you'd like to say about your initial hiring?

\section{HOLLISTER: No.}

LIGHT: So then do you recall what some of the major issues were during your tenure?

HOLLISTER: Well, I just described one with the collection of the dues.

LIGHT: Basically, what were some of the major challenges or major issues that you tackled?

HOLLISTER: Oh, there was one challenge, and that must have been back in the time, I guess it was during the time between Gordon Smith and Joe Cunningham (two executive directors), I was the acting executive director at the time. During Don Madden's tenure, we set up for the staff a TIAA-CREF annuity plan because we were not-for-profit. And some staff member had the bright idea that ACM could do better than TIAA by going out of TIAA. If I remember correctly, the organization they were proposing was Prudential. You know anything about Prudential? It was certainly of long term benefit to ACM staff that we were able to retain the TIAA plan.

All right. Now, where were we?

LIGHT: Okay, so the big question was major issues or challenges during the time that you held the position.

HOLLISTER: Well, also the-- I'm trying to think. I think the SIG staff person dedicated to working exclusively with SIGs, was set up under Jean Sammet's tenure. I came up with the idea, because the SIGs were driving us crazy, the SIGs were multiplying, and getting very aggressive-I mean in a nice kind of way-about wanting services and so forth. And so with the staff we had, there were just too many things that the SIGs needed that we couldn't provide. So I was able to get a dedicated staff member to handle the SIGs. By the way, do they have special interest committees?

LIGHT: You know, I don't know intimate details. I know that there are SIGs that thrive, whether it's committees or groups... 
HOLLISTER: It used to be you started out as a SIG committee, and then you went to a SIG group.

LIGHT: Oh, so once you had a certain number of people...

HOLLISTER: A certain amount of interest. I think the philosophy was it was easy to set up a committee, but you had to prove that there was enough interest and backing to go to a more formal organization.

LIGHT: Well, I know a lot of small elite societies do that now. I don't happen to know what the ACM's procedure is.

Okay, let's see. Well you've just been talking a little bit about the structure of ACM. Are there thoughts you have about changes to the organizational structure during your service and how that impacted your job?

HOLLISTER: Well, we moved from the brownstone to an office on East $40^{\text {th }}$ Street. That was some time in '62 or ' 63 and in '64, they hired the first executive director, Don Madden. At that point they needed to have somebody who could talk to the membership in technical terms. Then we moved to $6^{\text {th }}$ Avenue under Don Madden. And it must have been the glory days because we had a wonderful office. We had two kitchens, and a computer room.

LIGHT: Now were you involved in picking out all of those office sites or just the first incarnation?

HOLLISTER: Well, I did the first one and I did the second one, and I saw to the construction and decoration of the second one. But I worked closely with Don Madden on the third one at $11336^{\text {th }}$ Avenue. I worked with the real estate people and the decorators. Anyway, eventually during hard times we had to give up those two-- the very nice lunchroom for the staff and the little small kitchen for the executives.

LIGHT: Oh.

HOLLISTER: We had to pull back. I think this was around the late '60s and '70s.

LIGHT: So, do you have any thoughts about public perception of ACM during your time?

HOLLISTER: There was a to-do about the name. What do they call it now?

LIGHT: It’s ACM still, the Association for Computing Machinery.

HOLLISTER: Didn’t they do away with the Machinery?

LIGHT: Not to my knowledge, no. 
HOLLISTER: Because there was a big fight, if you will, about getting rid of the word "machinery", because the conception was that it was a machine-oriented or engineering organization when of course the environment was software.

LIGHT: Right. Do you remember when this particular issue flared? Are you saying you think it was...

HOLLISTER: Well I think they actually went to the membership for a vote. There were just too many people who were still there from the beginning who voted for retaining the original name.

LIGHT: Well, I think it's such a prestigious organization that in many ways changing the title, then it would lose the meaning even in a public sense.

HOLLISTER: Yes, yes. And I can't remember when that was. Must have been in the '70s sometime. Pat would know better.

LIGHT: Okay. So now we have a couple of technical sections about what did ACM have to offer programmers and analysts? How important was numerical analysis in scientific computing? Do you have thoughts on those subjects?

HOLLISTER: Yeah, see the organization has changed greatly. I retired in '86-'87, and that's just the time when the personal computer came into being. Interesting point. I can remember Herb Grosch saying at a Council meeting that the personal computer was for hobbyists. So even those people who were so bright, all of them, did not foresee-- Well, neither did IBM, right?

LIGHT: Right, exactly!

HOLLISTER: So we were in good company!

LIGHT: Exactly.

HOLLISTER: So I left just at the time when that was beginning to...

LIGHT: Okay. Well, one of the things you had talked about a little bit is the relationship between ACM and the British Computer Society. Were there other organizations that you remember having relationships with, and how would you characterize them?

HOLLISTER: Of course the IEEE. We always had a relationship, a certain amount of cooperation, a certain amount of friction. At one point, the IEEE did the computer processing for us. This was before we had our own computers. We had IBM tabulation equipment in the 1960s. And then later we got our own computer staff. And that was an interesting, thing because with the budget that the office had, they could just afford to hire computer programmers and operators. Well, of course the volunteers were dealing with people who were at the forefront of research. So they sometimes had it difficult time understanding why it took us so long to do or why we were so far behind in the operations. Well, we couldn't afford more you know. So that was always interesting. But I think somehow Pat has solved that problem. 
LIGHT: These are very helpful recollections that you are offering. Okay, so...

HOLLISTER: I'm trying to jog my memory. I went back and looked at some things. These are letters for the most part that were written to me. Well, this was 15 years and this was at retirement [shows the letters].

LIGHT: Oh my goodness.

HOLLISTER: But I came across one that I think was particularly interesting [flipping through pages]. Now I'm going back to the early days. This was from Herb Bright, who was the secretary. Unfortunately my fax machine is not working, so I can't make you a copy of it now. He says, "I wished I could claim to have been instrumental in hiring you as ACM's then only employee, but I believe it was Gilchrist. You must remember our first face-to-face meeting just a week or two after I took office as secretary in the Perlis administration. We had had a series of increasingly tense telephone discussions about what the advertising agency was doing to ACM's public image by using sales methods that offended both of us and perhaps the association's tangible assets by unusual filing and creative accounting practices. As I walked to ACM's office for the first time, I recall wondering whether this shabby, genteel apartment location could really be a place I was looking for, and if so, if ACM might be in violation of some law conducting a business from a residential property. Answers: yes. Don't care. The agent wasn't taking our calls. On advice of counsel good old Dick Davidson, rest his soul, we notified him by registered mail that we'd invade his office and carry off ACM's files having terminated the contract." He was selling our mailing list and he was also selling advertising for us. I don't know what he was doing, but it wasn't right. "It seemed like something out an old whodunit movie as we proceeded from the subway station through the windblown dirt and scrap paper to his walk-up office. He wasn't there, of course. I have often wondered just how we talked his helper into letting us make off with the files.” I will make you a copy of this.

\section{LIGHT: Please!}

HOLLISTER: It's two pages. I won't go through all of it. Okay. The Perlis era was less formal than the Sammet area. This must be during Sammet's time. Al didn't show up for all the Council meetings, so Bruce Gilchrist got some exercise as chairman pro-tem. In those days, it was the secretary's (my job) to prepare the budget. I believe it was during the first Council meeting you attended that I realized, whoops! I'd nearly forgotten to prepare the budget. After a certain amount of flack from my colleagues, it was agreed that I would leave the meeting for a couple of hours and do the job. I did so. Nowadays the budget we process is handled somewhat more formally. Let's see [flipping pages].

The mailing list, that was a problem in the early days because it was extremely valuable. And people were using it-- I think that's one of the things that was problem with the man who had the files, that he was selling them.

The most exciting incident had to be Kelly Gottlieb’s phone call insisting that we had to junk a page-proofed, not-yet-mailed issue of Communications because it contained a full-page ad for a computer "as fast as a 7090 at a quarter of the cost". Kelly was upset because he felt we might be misinforming our members. He didn't think a 24-bit machine with $4 \mathrm{~K}$ core and no input-output except a flex writer was truly equivalent to a minimum 7090. Again, on advice of counsel, I phoned the maker to ask him to withdraw the ad. Sed Maker [?], one of the more 
colorful characters in our biz, replied that ACM had accepted the ad and that if we censored it (in violation of First Amendment), he'd sue us before we could blink. Faced with that prospect, Kelly agreed grudgingly that our membership be able to tell the difference and that he as editor had less responsibility for the purity of the advertising than the hard text.

[Break]

LIGHT: So we were talking a little bit about relationships with IEEE and the British Computer Society. Were there other organizations or do you remember anecdotes?

HOLLISTER: Well, there was an organization (I don't know if it still exists), BEMA, it was called: Business Equipment Manufacturer's Association. And that organization, and maybe it still exists, set the standards for the industry. It was an industry-sponsored organization. And a lot of our volunteers served, well, they didn't serve on the board, but they served on Committees that set the standards for software and equipment. It had a big influence on setting standards, in those days anyway.

And the IEEE and then of course the AFIPS. JCCs - that's an interesting story. We had this little brownstone that had two rooms in it and a tiny little kitchen and a closet. And one morning, early on, I approached the office, and here was this huge trailer parked in front of the office. The truck driver informed me that they had our part, ACM's distribution of the papers from the meeting of Western Joint Computer Conference. I wonder if it was 1960 or 1961; I don't remember. And he was about to unload all of those publications, I don't know how many there were, on the doorstep! So I had to arrange very quickly to get them put some place, and I think I put them in a place where-- Herb Bright talks about the advertising manager. He took them for a while. I do remember the driver insisted that we take a certain number, and I think we broke the elevator getting those up!

And that's another thing where when I was hired, there were very few people-I don't think there were any people who really understood some of the things that were involved in running an office, like the distribution of the JCC papers.

Okay, what else? Let's see.

LIGHT: So did you have any role in trying to define the mission of the organization during the time that you worked there?

HOLLISTER: Not from a technical point of view. But certainly from an administrative point of view, such as the collecting of dues and being sure that volunteers didn't speak for the organization. If they did, it had to be approved by the executive committee.

LIGHT: And are those some initiatives that you went about proposing?

HOLLISTER: I think it just grew.

LIGHT: So then we have some questions about the internal organization of ACM, which you may or may not have thoughts on. Relationships inside ACM, like what were some of the most active ACM boards, SIGs, and other committees, and the relationship between these groups and the central organization? 
HOLLISTER: I do remember when SIGGRAPH came along, they started to have their own annual meetings, and it was such a growing field. And they had such successful meetings and made so much money, that it was a question of what entity the money belonged to, SIGGRAPH or ACM. But I guess they resolved the problem, it was almost a case of the tail wagging the dog, because ACM would have an annual meeting and they would draw 3,000 people. SIGGRAPH would have a meeting and they would draw 40,000. I think it was that high in those days.

LIGHT: How much of that money went back to ACM central...

HOLLISTER: I don't remember, but there were problems. You see, as the organization grew, and even the staff grew because, when I left I think they had about 100 staff. And so you get farther away from the details. But I'm sure it could be researched.

LIGHT: You mentioned SIGGRAPH as doing work that obviously was attracting many, many people to their meetings. Were there other SIGs that you thought were doing especially interesting work or also attracted large numbers to their meetings?

HOLLISTER: There was also something of a problem with the artificial intelligence group. I think eventually that group broke away from ACM. But those are the only two that really stood out.

LIGHT: Now did you have relationships with ACM boards like the Publication Board, the Education Board, Membership Services Board? And do you have any recollections of interactions with those groups?

HOLLISTER: Well, the Publications Board I didn't have much to do with. Myrtle took care of that, it was her area. And once we hired somebody to do the administrative work for the SIGs, dedicated to the SIGs, then I got less involved.

LIGHT: Okay, so you're saying there are other people in the organization who had closer relationships with each of these boards. Okay. And then I suppose the same question goes for the ACM committees like Coalition of Diversified Computing, Committee on Women and Computing, Computers and Public Policy. Did you have any relationship...

HOLLISTER: They didn't exist when I was there.

LIGHT: They didn't exist? Okay. So then the next group of questions is about administration at ACM, some of which we've discussed a little bit. But there other specific questions, like who were the officers that you worked most closely with?

HOLLISTER: Oh I worked most closely with the secretaries and of course the executive directors. Let's see, Herb Bright; Bruce Gilchrist; George Forsythe, who was the president. He was a lovely man. He really was very nice. Tony Ralston I worked closely with. Charlie Bradshaw, the secretary. Don Parker. Anyway, all of them, usually I worked most closely with the secretary. 
LIGHT: And do you have any either stories about any of these folks or reflections on their different professional styles that you think are noteworthy to mention?

HOLLISTER: Well, I worked very closely with Charlie Bradshaw on the bylaws for the SIGs and SIG board. The man I worked with in revising the ACM bylaws? Another nice man. He was the designer of system 60, IBM 60. Sorry. It's just gone! You know, you're asking me to go back 50 years here! [Laughs.]

LIGHT: Oh, it's okay. Listen, we're very happy with whatever information and anecdotes you provide.

HOLLISTER: Let me see. Oh, here are some of my stories. Grace Murray Hopper. Did you ever know her?

LIGHT: I’ve never met her personally, but I know about her.

HOLLISTER: She was about 5'1”, and she was a captain in the US Navy. The Navy was the one that had the original ENIAC contract. During the Vietnam War, that time when there was so much public pressure against the war. For some reason the executive committee or some people on the executive committee thought they really needed to identify the founder of ACM. They decided they would name Ed Berkley as the founder. So it must have been an ACM meeting, or annual meeting, they had a ceremony at the banquet to recognize him as the founder of ACM. Ed Berkley was a person (I didn't know him very well, but I knew some of his reputation), he was a person who was difficult to control [laughter]. And he, in accepting this honor, got off on the Vietnam War and the fact that we shouldn't be there, and on and on. Well, Grace was sitting up in the front of the big banquet hall, at one of the front tables, when he started off on this rant about the war. She stood up — she was in full uniform — and turned around and quietly, slowly walked the full length of the banquet hall, out of the hall. She was something. I was right after her because, I felt it was my responsibility to prevent any disruption. But she was all right. But she didn't say anything once she was out in the hall. As a military officer it was her way of supporting the US government!

LIGHT: And did he just keep on...

HOLLISTER: He just kept on. I think he published his own newsletter. I have a slight memory (and somebody can check it out) that Pat McGovern worked for him early on.

$\mathrm{Oh}$, and also, the story of the bug. I heard Grace Hopper tell that story, she is the one who was involved in leaving the message.

LIGHT: And did she just recount it to you, the two of you, or were you in a meeting where she was giving a public presentation? Do you recall?

HOLLISTER: I think it was in the meeting. It wasn't a big meeting, though. There were several people. Do they still have student chapters? But anyway, she was wonderful with the students. She really was. She would go any place, no matter how remote, middle of winter, to give a lecture to students. She really cared about students. And during Gordon Smith's term as executive director, he got UNIVAC to put up money, sponsor the Grace Murray Hopper Award. 
And I don't know if it was the first award or whether it was close to the first award, but he had a luncheon or a breakfast honoring the first recipient, and it happened to be somebody who came out of academia, don't know whether he was working at Harvard or MIT. It seemed to me it was one of the Boston universities. She was sitting at the table with him and other people, and she turned to him and said, "You're not the kind of person I had in mind when I set up this award." [Laughter] I was sitting there at the table-oh, what an insult! She was very forthright. I guess she had in her mind she wanted somebody who was working in the garage. Well, this was a little bit before the time when there were people working in garages.

LIGHT: Well, we have a couple of questions here about staff at ACM headquarters. We've been talking about that quite a bit. But do you have recollections of other misunderstandings with the membership? You mentioned issues about collecting dues and then the slowness to disseminate publications. From your position kind of looking out over the organization, do you remember moments of tension with members or volunteers?

HOLLISTER: With the SIGs. That's why we set up that dedicated staff member because we couldn't handle all of their demands.

\section{LIGHT: What kind of demands would they make?}

HOLLISTER: Well, printing their publications. During Bruce Gilchrist's time, we went from an annual year to a fiscal year. The IEEE, I don't know if they ever changed, but they were on an annual basis, so everybody expired at the same time. One of the ongoing problems was always supplying members with back copies. People would not renew on time, and then you'd have to go back and figure out how many publications they were due, and of course, which four publications-- it got to be a real administration problem. We used to try to do this from the office. But we finally signed a contract with Waverly Press so that we would make up the orders and they would mail the publications.

Another thing is-I'd forgotten this. There are a lot of complaints when you're servicing 30,000 to 70,000, four publications, etc., in a complicated organization. Some of the volunteers thought that once we got things up-to-date, there wouldn't be any more complaints. Well, we finally convinced them that it was an ongoing service and should be renamed ACM Membership Service Group. You are always going to have things that you have to take care of for the membership: lost checks, changes of address, and so forth.

There's one thing that I didn't talk about -- I remember this specifically during Jean Sammet's time, when she was head of the SIGs and also when she was president. We always had a difficult time justifying to her the need to have somebody doing promotion work — not advertising because that was for the publications board. But she could never see it...she was always saying, "How can you tell? How can you justify having somebody on the staff to promote the..." That was part of the tensions that went on during those days.

LIGHT: But in the end you kept on...

HOLLISTER: And then we were able to shut her up, yes. [Laughter] I was very fond of Jean. She is a very good person. 
LIGHT: Can you think of any other organizational challenges that you had to deal with, with your main role in the office?

HOLLISTER: No, just IEEE. Well, AFIPS also. At one point, we sublet an office to the executive director of AFIPS. This was before they moved to Washington.

LIGHT: Okay. So then we have a whole category of questions about computer science education and training. I'm not sure...

HOLLISTER: No, I think we skip all that.

LIGHT: So questions about financial aspects of the organization. Many organizations, especially not-for-profit, are often in kind of a financial crisis situation year after year. How would you describe the financial stability or instability of ACM?

HOLLISTER: Well, when I first started we had 8,000 members, and when I left we had 75,000. And we had two publications when I started—we had just started Communications. The journal was the first publication, and that was started by Franz Alt. I think that the membership now, the last time I checked was a couple of years ago, is still around 75,000. But it's my understanding from a conversation I had with Pat, that somebody has recognized that there's a gold mine in the publications of the Association, and they apparently have bundled it together and sold it as a service, an archival service of the publications.

Also, at one point-I noticed this with several other organizations that I'm privy towhen you have a new field, when something is beginning, the people involved-this is true also of studio glass, that my husband was involved with, writing about it, lecturing about it. The people involved are very open. They want to share because it's new. The ideas are flowing fast and furiously, and there's a sort of openness. And this happened with an ACM paper. Because of my lack of a technical background, I can't tell you what the paper was, but it appeared in I think Communications (I don't think it was in the journal). But I think UNIVAC picked up something from that paper or were able to see something in the paper that they could use profitably. The author of the paper, I guess sued UNIVAC for use of it. This is all very vague in my mind, but I do remember that Myrtle testified in a pre-trial deposition, and she did it all by herself, with a set of lawyers on each side. I think that she testified the full-maybe it was over two days. It was four or five hours. Somebody might like to check into that. Now who would know more about that? Myrtle would know, but...Bruce Gilchrist might possibly be able to... But it grew out of this fact of sharing, but then some sharpie picked it up and it could have been, maybe was, very profitable for UNIVAC.

LIGHT: I think we have a comparable situation today with things like open-source software that a community of people want to share but then all of a sudden someone comes along that wants to profit.

HOLLISTER: Yes, sees some way of making a profit. Yes.

LIGHT: Yes. So back to the issue of the financial health of the organization. Was it something that you worried about? You know, where is the money going to come from? Gosh, we need to 
have more members so that the central office can stay afloat? Or were you pretty much well taken care of and that's not something that you worried about?

HOLLISTER: Well, we lost some members, of course, and our membership did dip at one point when things got very rough. I believe it was in the seventies, when a lot of computer people were laid off. And then of course, that always had an impact on staff, trimming down the staff.

There was a question about Franz Alt. And I have this letter that he wrote when I retired.

LIGHT: Right, about his role as editor.

HOLLISTER: He started the Journal, and he was still I think at the Bureau of Standards at that point. He hired Myrtle (I think Myrtle worked with him at the Bureau of Standards) to do the editorial work. He was a very nice man. He was Viennese and highly respected in the profession. When he retired and was sort of looking around for something to do, he got in touch with some small volunteer organization. He went to say, "I'm here. I'd like to volunteer. Is there something I can do?" And the man he was talking to said, "Well, are you good at figures?" "Yeah, I guess, sure." "Well, we need a bookkeeper." Franz said, "Okay." So he took care of the books for this small organization. I think this is just indicative of the kind of person that he was. He wasn't too proud to you know... and he was not a person that pulled rank. Okay. That's my story about Franz Alt.

LIGHT: So if you could think over the broad sweep of your career, would you say ACM changed substantially, other than things that you've mentioned, like it grew as an organization? Did it change somehow in character?

HOLLISTER: I think it changed a great deal. Well, for instance, the personal computer and the Internet. As I mentioned before, somebody realized the gold mine that they had in the publications. I keep up my contact with Pat because I'm proud of having hired her. And also Lillian Israel.

LIGHT: Oh, I don’t know her.

HOLLISTER: Well, Lillian does the promotion for them.

LIGHT: And they’ve been working at the organization for decades as well.

HOLLISTER: Yes. Pat has been there for almost 25 years. And I would guess Lillian, it's got to be more than 20 years because it's 20 years since I left.

LIGHT: So you talked a little bit about Edmund Berkley. Do you have any other reflections on the early history of the organization? Whether about him or other individuals who don't get as much credit as he does?

HOLLISTER: Well, Myrtle should get a tremendous amount of credit, because Myrtle was very dedicated to the publications. And I remember her telling me at one point, she had somebody working in the office who went by the book, you know. If you needed a period here, a period had to go here, and so forth. And Myrtle, because she knew many of the authors that she was 
working with, and she also knew the field because she'd grown up with the field too, coming out of mathematics, she grew up with skill. She tried very hard to walk a line between having everything absolutely according to the style book and keeping a flavor of the author or the insight of the author which was more important than having it absolutely grammatically perfect.

And here are two stories about Myrtle. Myrtle was very proud of the fact that she was a professional. When we moved to the office on $40^{\text {th }}$ Street, the office was arranged so that there was a little conference room and then sort of a suite of two rooms together, a place where a clerk or secretary sat between the two. When we moved there, that office went to Myrtle because it was sort of, to a certain extent, a little isolated from the other offices. And Myrtle, bless her soul, never came to my office. I ran the office, right? She never came to my office. When she wanted something, I always had to go to her office. But eventually we became very good friends. It never bothered me, I was rather amused. So when Don Madden was hired as executive director, that's where he wanted his office. So she had to move out of there and got one of the offices that lined the back wall. Well, it just so happened that there was a clerk desk outside of each one of these offices, and the clerk who worked outside of Myrtle's office opened the mail and stamped each piece of mail with a number from a numbering machine. So here is Myrtle who'd just been, if you will, kicked out of her office, working on things which requiredit's absolutely true-required concentration, and here is this girl sitting outside her office going [pounds the table, laughing]. I don't remember how we solved the problem, but we must have solved it!

\section{LIGHT: I would have gone insane. [Laughs]}

HOLLISTER: The other little story about Myrtle was that she had a girl—to whom she farmed out some of the editing. This is what you do when you don't have a lot of staff, you farm things out. I'm sure you know this. And the girl was a little strange. She apparently was brilliant when it came to editing and her knowledge of mathematics. But she would come into the office to pick up the papers, her hair would be sort of straggly and she looked sort of loopy. And she wore overshoes, plastic overshoes, the kind worn over shoes, but she never wore the shoes! She would come in with these plastic shoes, and looking all bedraggled and so forth. Myrtle respected the work that she did. However, she lived alone and she lived with cats. So Myrtle would absolutely insist that when she gave her the papers to work on, that they be put in a plastic bag and sealed. And when the girl worked on the papers, she took the papers out and then when she finished doing that, she put them back immediately into the plastic bag. Myrtle would get this work and she'd open the plastic bag, and she'd, say "Eww" and wave the papers to freshen them. [Laughter] But anyway, she respected her and what she could do. So that was funny. Okay.

LIGHT: Creative personnel management. Okay, so one of the things that historians write about with respect to computing is that federal investment in the Cold War played a major role in encouraging eventually innovation in computing. During the time that you worked at ACM, were you at all involved with interacting with folks in the federal government, in the military research labs, anything like that?

HOLLISTER: Hm-nmm [no]. We had a lot of members and we had contact with those main research organizations that were government-sponsored through members and subscriptions. I guess they don't have the government support as much today. 
LIGHT: Well, do you mean places like Livermore Labs, I mean, those are still in operation, but you know, the really important era was the time that you were at ACM.

HOLLISTER: I didn't have much to do with it. We did have a problem at one point-it's not government but it was international — with the Arab countries, Saudi Arabia, and so forth. They sent us forms to fill out, before they would buy our publications, that stated we were not doing business with Israel. Fortunately we responded, "Sorry." We are an open organization. But I do remember that, we didn't sign that stuff. They bought publications under our rules. But I don't remember much about the Cold War in relationship to ACM. However, we tried to supply publications through rather devious ways to people in Russia and behind the Iron Curtain.

LIGHT: Oh.

HOLLISTER: Yeah. And tried maybe to sponsor some of the people who wanted to get out.

LIGHT: So you've mentioned some of your successors and how you think the world of them. Do you have anything more to add about any specific successors from your position?

HOLLISTER: Well, I guess there’s just Pat, right?

LIGHT: That's it, after you? Okay.

HOLLISTER: Yeah. Let's see. Pat was working directly for me, and then when I left, she reported directly to the executive director. I think that's the way it worked.

LIGHT: And do you have any specific comments you want to make about her?

HOLLISTER: I think she's an absolutely wonderful person, and very bright. When she first came to work for me, she was my secretary or administrative assistant, if you will. The procedure was that if mail came in addressed to a volunteer, say the president, we opened the mail, read it, and very often it was "Please send me my publication" or "I missed...my dog chewed it up" and that request could be taken care of by the staff. But if it was marked "Personal," then it was forwarded on to the officer. A letter in Spanish came in addressed to the president, it was Bruce at that time. So Pat was opening...I think she opened all the mail that was addressed to volunteers at that point as part of her job, and when the letter came in to me to be reviewed, she had translated it all into English. She had done it on her own. I didn't have to say, "What do we do with this?” or anything. She had just done it, so it could be sent on to, I think in this case it was Bruce, all translated. And you know, it's that kind of initiative that showed up very, very early. Very early. I think she’s done a wonderful job.

LIGHT: One of the things we have a full section on is advice for the future. Do you have things that you would like to see the current organization take on that it's not?

HOLLISTER: I have no opinion at all. I'm so far from it now. 
LIGHT: Okay. Well, I suppose then the last section is a few more details of life history so we have fuller background, and then if there are other reflections that you came up with just in reflecting on this broad list of questions. We could talk about those, or if you have thoughts or questions that I could've asked you but did not, I'm more than happy to discuss. So you told me your educational background and place of birth. Is there anything about your family history or marital history that you think is relevant to your professional career at ACM?

HOLLISTER: No, the only thing I can say is my husband was in a completely, completely different field, he was an artist, a writer, and a lecturer in the Decorative Arts. He taught at the Cooper Hewitt Museum. He taught the history of glass for ten years. He edited a publication of an organization called the Early Glass Club for ten years. That was all on glass: collecting glass, antiques glass, studio glass, and so forth. He was not involved in ACM in any way at all.

LIGHT: Actually, I'm curious to know, because we talked earlier that your background was not in math and computing and you found yourself working for the organization. Did you become interested in computers as a result, or you only saw your role as helping people with expertise in computing and math run the organization?

HOLLISTER: Yeah, I think it's more of that, because you see, when I was working for ACM, you had to have a professional background in mathematics or physics or in computing in order to be technically involved, and I did not have that; my background was in business. You pick up some things; you can't help but pick up some things, but it was nothing I could use for... You see, at this point, it's quite different. I don't know how much the profile of an ACM member has changed from what it was because early on they were strictly all professional people. They were so intelligent as a group, and also their standards were very high, their intellectual standards and their moral standards. Of course, I say moral standards-I should ask you, do they still have that SIG Booze?

LIGHT: SIG Booze? What is that? [Laughs]

HOLLISTER: Well, at the annual meetings, they always had one night of partying, and it was called SIG Booze.

LIGHT: That's so funny!

HOLLISTER: Which I did not participate in, but apparently there was some pretty wild stuff.

LIGHT: That's really funny. Well, we'll have to check that out.

HOLLISTER: Yeah, have somebody check out SIG Booze. The people mostly involved in SIG Booze were David Brandin; Jim Adams, who was a staff member; Walter Carlson; Tom D'Auria. They were the organizers of those late night parties.

LIGHT: Now, in your retirement, what have you been doing? Because I know that's something that people would like to know. What have you done since you left ACM? 
HOLLISTER: Well, I've worked mostly with Paul's paintings and writings. Just shortly before he died in 2004, we completed a catalog of all his oil paintings. I now try to market those paintings that are still left. Before he died, he wrote a memoir of his early life when he lived on Davenport Neck in New Rochelle, New York. He lived in a house that was built in the 1600s which later became a national landmark. And the period from 1926 to his early teens, is the time of the memoir. And I'm now in the process of trying to find an agent for the bok because I would like to publish it. It's an interesting story because he was a good writer.

LIGHT: So you've been fairly busy!

HOLLISTER: So that is what I have been doing. Yeah.

LIGHT: Well are there questions that I have not asked?

HOLLISTER: No. Let me just run through my list again.

LIGHT: Sure. Take your time. It's wonderful.

HOLLISTER: Because I've been wandering around a lot. Oh, one thing was interesting. When ACM first set up - the Turing lecture, that was the time volunteers were collecting dues. I tried to limit the administrative functions of the volunteers. Projects Something that had a start date and a finish date rather than have volunteers get involved in ongoing administrative functions. Anyway, it as before we got the awards under administrative control. The meeting happened to be in New York. I was cleaning up, packing up the stuff in the office, ready to go back to our office after the meeting was over. This gentleman wandered in and said, "I just gave the Turing lecture. Am I supposed to get some kind of an honorarium?” [laughs] The volunteers had made the arrangements for the lecture. His name was, as I remember, Wilkerson-well known, internationally known. He was British. They had made the arrangements including the lecture and publication of his paper in the ACM journal, but nobody bothered to tell the office that he was due, an honorarium. It was a most embarrassing moment for him and for us. I mean, I thought, "Oh my god, what a blow to ACM's reputation." But fortunately, the meeting was in New York, so I could call the office and say, "Get a check ready and find Gordon Smith,” or whoever was signing checks at that time.

LIGHT: Right. Well, I think that speaks to the point about the volunteers versus the paid staff and how you might approach things differently.

HOLLISTER: That's right. Each has a role to play in a complicated organization such as ACM. Another interesting thing. The first time I can remember that we had a meeting in Las Vegas, and in the early days of Las Vegas, every hotel had an open buffet. The food was free. Then they learned that they could sell the food! But that was in the very early days. I of course at that point had no help and would run the membership table, selling memberships and publications and taking people's complaints. At the end of the meeting, I had a great many silver dollards. The casinos didn't allow any dollar bills in Vegas. No hotel would give you a dollar bill in change; you got silver. So at the end of this meeting, I had a huge bag full of silver dollars! The hotel wouldn't change it for me because they didn't have any dollar bills, and I had to find a 
bank in Las Vegas that would change the coins into paper money and it just so happened to be the weekend.

LIGHT: That's funny, yeah.

HOLLISTER: I'm sure that such nonsense does not exist in today's world.

LIGHT: Well, I think they give single dollar bills, too because silver dollars are a little heavy!

HOLLISTER: They probably have machines that take more than dollar bills now.

Oh, we also had a lecture program, and I don’t know whether it still exists. Jim Adams at that point was the director of education, and he and Dave Brandin and somebody else whose name I don't remember, would run what they referred to as the dog and pony show. They would give these lectures and also instructions in cities throughout the country. You didn't have to be a member to attend, but it was a moneymaking project for a while.

LIGHT: Do you remember around when that might have started?

HOLLISTER: [Flipping pages] Well, it started during Don Madden’s tenure. It could have been as far back as '65, and continued through I'd say the '70s. I don't remember what happened to it. I guess there wasn’t enough interest in it for some reason.

And you know, ACM had a library at one point.

LIGHT: Oh really. In New York?

HOLLISTER: Mm-hmm [yes], in New York. When we were on West $40^{\text {th }}$ Street, they had a library and a librarian. It was eliminated because it began to eat up space. I think that it probably lasted maybe four or five years. This is really going back. I believe the library material was sent to the University of Pennsylvania. Is that where the Moore School is?

LIGHT: Mm-hmm [yes], yeah.

HOLLISTER: Yeah, it was at the Moore School at the university. ACM was trying to find a home for the archives.

LIGHT: So that the papers went somewhere after that [inaudible; overlapping voices].

HOLLISTER: Yeah. I don't know whether they it sort of disintegrated or what happened. But we did for maybe three or four years have a library, and then we gave it up because it was too expensive for us to keep.

AFIPS doesn't exist anymore, does it?

LIGHT: I think it does. I think it might be IFIPS now.

HOLLISTER: That's the international.

LIGHT: Right. Oh, were they always different from one another? 
HOLLISTER: One was AFIPS, American Federation, and the other was the International Federation.

LIGHT: Okay, well in that case, it may not exist. I'm not sure.

HOLLISTER: Yeah, because as I remember it was not well managed. ACM rented office space for the AFIPS executive director. Later, they set up their office in Washington. This was in the mid '60s. They grew quite large because the Joint Computer Conferences became very profitable. They did not have individual members; their members were organizations. I remember the story. At the end of those conferences, when they would move out all of the equipment, he used to stand with a fistful of money, probably \$50 dollar bills, and hand it out to truckers, hotel staff and so forth. And it's my impression that they went under partly because it was not well run. But also it probably had something to do with the changing of the profession and the technical aspects of the profession. I think also there were too many competing organizations sponsoring meetings.

I think I'm about talked out.

LIGHT: Okay. Well, this was wonderful. I mean, you anticipated in our early conversation a lot of later questions, so I think we've gotten quite comprehensive responses. Well, thank you so much for your time.

HOLLISTER: You're very welcome. 